\title{
Sustainable Livelihood of the Community in Tasik Chini Biosphere Reserve: the Local Practices
}

\author{
A. Habibah (Corresponding author) \\ School of Social, Development and Enviromental Studies \\ Faculty of Social Sciences and Humanities, Universiti Kebangsaan Malaysia, 43600 Bangi \\ E-mail: ha@ukm.my \\ J. Hamzah \\ School of Social, Development and Enviromental Studies \\ Faculty of Social Sciences and Humanities, Universiti Kebangsaan Malaysia, 43600 Bangi \\ E-mail: hj@ukm.my \\ I. Mushrifah \\ Tasik Chini Research Centre, Faculty of Sciences and Technology \\ Universiti Kebangsaan Malaysia, 43600 Bangi \\ E-mail: mush@ukm.my
}

\begin{abstract}
Tasik Chini, the second largest fresh water lake in Malaysia is the land of Aboriginals or Orang Asli typically known, Orang Jakun. The Jakun community is highly dependent on the local ecosystem for their livelihood during the early years of their settlement in surrounding areas, particularly on the richness of the 12 sea or lauts of Tasik Chini. The mainstay of its economy in the last two decades was mainly forest based activities, including fishing, hunting and herbs gathering. However, due to the expansion of market economy in the late 1990s, tourism, mining and logging were allowed to take place in Tasik Chini. Nevertheless, such development had resulted in a substantial depletion of natural and cultural resources. This has called an urgency for the establishment of conservation and restoration plans and most importantly, a global initiative of making a nomination for Tasik Chini to be designated as the pioneer Biosphere Reserve in Malaysia. Definitely, this new concept has risen many questions on the Jakuns' livelihood, especially on matters concerning their preferences and practices in the economy, social, cultural and environment. Based on survey results of six kampongs of Tasik Chini in year 2007 and two consequent visits to Kg. Gumum and Kg. Tanjung Puput in 2008 and 2009, this paper aims to delineate the situation, especially the existing livelihood and their socio-economic involvements as well as to gauge the local's knowledge, aspiration and participation on Tasik Chini as Biosphere Reserve. This paper is written in three main parts. Part one describes the Biosphere Reserve of Tasik Chini. Part two elaborates the livelihood and socio economy condition while part three provides matters concerning Tasik Chini as Biosphere Reserve. The findings revealed that the local traditions supported the sustainability of Tasik Chini, while the penetration of the modern plantation economy and ecotourism have helped them to experience better livelihood.
\end{abstract}

Keywords: Sustainable livelihood, Jakun, Socio economy, Wealth creation, Local tradition, Local practices

\section{Introduction}

Sustainable livelihood has long been one of the focal discussion in the sustainable development approaches, especially in areas of the marginalized people in under develop and developing countries. Many of the cases of the protected areas and forest reserve, have shown that there exist conflicting ideas of conservation and development, especially on matters of allowing inhabitants to live in the designated areas. However, this is not so in the case of Biosphere Reserve, a global network of Man and the Biosphere Programme (MAB), which has a total of 564 sites in 109 countries (UNESCO 2010). With its multi functional benefits of conservation, restoration and development, the local knowledge and practices are appreciated of becoming the ways of achieving sustainable development. As such, Tasik Chini and livelihood of the Jakun community are demonstrated, to provide an example of how the locals perceived sustainable livelihood. 
Tasik Chini, the second largest fresh water lake in Malaysia is the land of Orang Asli typically known, Orang Jakun. The Jakuns normally reside around the lake, whereby their livelihood and socio-economic activities are highly dependent on natural resources, fauna and floras, richly found in the areas. Besides being a central settlement for the Jakun's community in Malaysia, Tasik Chini is also renowned as the tourists' attraction, especially among the nature lovers. Legends and mystical Khmer empire believed to be sunken in the lake complement its nature attraction (New Straits Times, 10 December 2007). Based on her uniqueness, in the 1980s and 1990s, Tasik Chini had received high volume of mass tourist arrivals, both, domestic and international. Her popularity, however, had dropped drastically in the early years of 2000 until 2009. Based on the research findings from the scientific expedition in 2004 and sectoral studies undertaken by the experts of higher learning institutions, particularly, Universiti Kebangsaan Malaysia, the ecosystem of the Tasik Chini was reported to be in a critical and 'dying' situation. Depletion of fishes as the source of protein as well as the disappearance of lotus, the iconic flower of the lake had threatened the sustainability of the livelihood of the locals of Tasik Chini (Mohd Shukri 2008). The occurrence of big flood in the year end of 2007 has worsened this scenario. As a result, the number of tourist arrivals has dropped drastically, and in 2009, only 4,000 tourists arrivals were recorded. Most of the reason given by the tour operators is the limitation of its attraction as an ecotourism destination. Somehow it is a blessing when the threats and problems due to the existence of cabomba species, widespread of rasau and sprawl of unplanned development, Tasik Chini, has attracted many environmentalists and NGOs to propose various programmes to save the lake (Begum 2005, Khoo 2008).

Bearing in mind that the above situation could accumulate more losses to the locals, the country as well as to the global society, issues and the future of the lake should not be left unattempted. The idea of nominating Tasik Chini as one of the Biosphere Reserves, a MAB-UNESCO programme was then put forward by the stakeholders. The Biosphere Reserve, which combines the conservation, preservation and sustainable development, is chosen because of its practicality, suitability and most importantly, support the sustainability of the national heritage. As of May 2009, Tasik Chini was declared as the pioneer of Biosphere Reserve in Malaysia (UNESCO 2009).

Basically several changes are expected to take place, change and debated when Tasik Chini embarks on programmes for conservation, rehabilation, development controls and sustainable lake management. Definitely, among the locals, those changes could have risen questions of equality of local consultation and decision making, especially issues pertaining accessibility to natural resources. Often, in many cases, the locals could have accepted and response positively if they were consulted during the process of nomination. On the other hand, when little consultation was made, they reacted negatively to the programmes or projects introduced or enforced to them (Campbell 1999). Kutay (1992) found that, environmental benefits of community participation exist when there was a close working relationship between the local community and the industry (in Campbell 1999). The higher the women's participation in the forest resources utilization, the better their contribution in the community's livelihood. Altogether, the literatures showed that the synergy of the stakeholders played important roles in making the Biosphere Reserve a successful story. It is the intention of this paper to explore the situation, especially the existing livelihood and their socio-economic involvements as well as to gauge the local's knowledge, aspiration and participation on Tasik Chini as Biosphere Reserve.

This paper utilizes three main sources of data collection. A primary source of data is the survey of 80 households staying in six villages in Tasik Chini, administered in 2007. The second source is the public campaign of Biosphere Reserve held on the $28^{\text {th }}-31^{\text {th }}$ August 2008, that helped the team to update important enquiries. The tertiary source is the in-depth interviews of selected local leaders of the community. This is especially in the case of Tok Batin informative conversation with the authors which provides further illustrations of the evidence. This paper is written in three main parts. Part one describes the biosphere reserve of Tasik Chini. Part two elaborates the livelihood and socio economy condition while part three provides matters concerning Tasik Chini as Biosphere Reserve. This paper concludes with suggestions on approaches of community based ecotourism and sustainable development of Tasik Chini. It is therefore, at the onset of not marginalizing and depriving them from using the resources for their livelihood, which in many studies, have shown that these seldom the case when come to protected areas and livelihood of the aboriginals around the world.

\section{Sustainable Livelihood of The Community Of Biosphere Reserves}

Issues of livelihood sustainability of the community have been gaining their popularity in the studies of conservation, protected areas and its support to sustainable development, marginalization of aboriginals as well as in the enhancement of community residing in Biosphere Reserve (Brocklesby \& Fisher 2003, Moran et al. 2007). The Biosphere Reserve, under the MAB-UNESCO programmes, is organized to achieve multi functional benefits of conservation, restoration and sustainable development. Studies on topics of Biosphere reserve are various and these include the landscapes, sustainable living, empowerment of the local communities and 
management of both natural and cultural resources. In fact, issues pertaining to the marginalized livelihood of aboriginals have attracted the social scientists, the government as well as the NGOs. While there are extensive examples of community's sustainability of the biosphere reserve, a comprehensive model that helps to demonstrate the tropical sustainable livelihood is, however, limited. In fact, wetland and lake basin studies of aboriginals are based on fragmented experiences. This is particularly obvious in the case of Malaysia, as there is only two natural freshwater lakes, Tasik Tasik and Tasik Bera, whereby it houses the Orang Asli, the Jakuns and Batik respectively. Therefore, this paper intends to comprehend the meaning of sustainable livelihood from the perspective of the newly proclaimed biosphere reserve, and it is the intention of the paper to focus on Tasik Chini Biosphere Reserve.

From the literature, several authors have regarded that sustainable livelihood should not only aim at addressing the economic issues and goals. Instead, it should offer multi-faceted benefits that include cultural well being, social bonding, environmental conservation and rehabilitation, and local acceptance of biosphere reserve as a whole. As such Chambers and Conway (1992) defined livelihoods and sustainability as:

... a livelihood comprises the capabilities, assets (stores, resources, claims and access) and activities required for a means of living: a livelihood is sustainable which can cope with and recover from stress and shocks, maintain or enhance its capabilities and assets, and provide sustainable livelihood opportunities for the next generation; and which contributes net benefits to other livelihoods at the local and global levels and in the long and short term. (in Moran et.al 2007: 2).

Even though the concept and interpretations of sustainable development had long been explored in various disciplines as well as at the national and international arenas, there exist an uncertainties of what matters the components of sustainable livelihood of the local community residing in and surrounding the biosphere reserve. Issues of the coping mechanism of the marginalized people in poor countries are still under-studied, especially as a field research (Moran et al 2007). Moran et al (2007) introduce a sustainable livelihood framework which encompasses vulnerability context, livelihood assets, transforming structure and processes, livelihood strategies and livelihood outcomes. The literature of rural and protected areas further enhance the connectivity of sustainable livelihood, which means that the rurals are very much intact with their environments. Even when they live with better amenities and experienced a higher standard of living, yet, they still possess a higher responsibility for conserving nature. In terms of questions pertaining to "who dominates the task of providing sustainable livelihood', many researchers have agreed upon what roles the communities and stakeholders have to play. Tao and Wall (2009: 95) agree that tourism is the key success for sustainable livelihood. Benefits derived from their involvement are seen in flexible hours of working, creating cash-earning opportunities and provide a back-up employment opportunity. However, they found that these opportunities are distributed unevenly and were concentrated around areas of good access.

Recent studies on Biosphere reserve are also concerned with sustainable livelihood of the community. The Tonle Sap Biosphere reserve, for example, provides a broader understanding of this concept and approaches in the core zones. Options and strategies of sustainable livelihood in the core zones of Tonle Sap would be based on the following priorities: i) activities that have no or easily managed environmental impacts. ii) Activities can be carried out at or near the home, iii) activities benefiting the poor families or those with otherwise limited access to natural resources; Activities that produce goods and services that will substitute for those currently obtained from the Core Areas. iv) Activities requiring low initial investment costs and produce early and consistent returns. In addition to livelihood activities per se, a number of environmentally friendly technologies that potentially reduce pressures on limited natural resources are identified (Tonle Sap Conservation Project 2006: 6).

Basically sustainable livelihood of the community staying in protected areas be they as the Biosphere Reserve or nature parks, should be viewed as the means of the local practices which enhance sustainability of the area, without depriving the locals to access modernization and high quality of likelihood. It is therefore, crucial to undertake this study to reveal the sustainability within the perspective of the Jakuns as the guardian of the locality.

\section{Tasik Chini as Biosphere Reserve}

Tasik Chini, situated in the southern east part of Pahang state, has many specialities. The lake and its ecosystem is rich in natural and cultural assets. It also functions as the water retention for flood control and state park for tourism development purposes. There is a diverse range of ecosystem within the Reserve boundaries. This ecosystem includes the significant freshwater lake, Felda plantation scheme and Orang Asli settlement.

Among the tourists, Tasik Chini is a popular ecotourism destination with a mythical legend of sinking ancient city of Khmer (New Straits Times 10 December 2007). During the influx of international tourists in the late 
1990s, some of the locals took the initiatives to develop tourist attractions in their villages. Pak Bahrin was one of the pioneers, offered the local livelihood and traditions to welcome tourists. They sold handmade blowpipes and handicrafts. Uncle Rajan, Batin Awang and Kak Nor are among the locals that ventured into providing the guest house and guided tours. They took the tourists to explore the 12 lauts, learned local ways of hunting, fishing, and jungle tracking.

In terms of changes and development, some of the watersheds in the Reserve have been extensively logged and cleared in the past fifty years. These include the land conversion into agriculture and plantation area, and others, subjected to varying types and degrees of human activities. The main lake and forest lands within the lake's catchment area are managed under strict guidelines to maintain ecosystem integrity and health. There are five villages where the residents are the indigenous people (Orang Asli) living near the freshwater lake. The main villages are Kampung Gumum (main village), Kampung Chendahan and Kampung Tanjung Puput, while four small villages of Orang Asli at Kampung Melai and Kampung Ulu Melai (Habibah et al 2009).

Bearing in mind that its specialities and uniqueness is pertinent to be conserved and inherited by the future generations, Tasik Chini was proposed and nominated to become the pioneer Biosphere Reserve in Malaysia. Tasik Chini offers three main functions of a designated biosphere reserve. The core area consists of the area required to meet the long-term conservation objectives; second is the buffer zone(s) and (b) the third region is the transitional zone, which act as areas suitable for working with local communities in demonstrating and utilizing sustainable uses of natural resources. The core area includes natural freshwater lake and its feeder rivers; terrestrial forest reserves surrounding the lake and water bodies as well as the dominant hill areas namely Bukit Tebakang and Bukit Ketaya. The freshwater lake and the surrounding areas have been gazette as Forest and environmentally sensitive land under rank, I (Protected Area in Peninsular Malaysia, Malaysia National Physical Plan). These areas have been categories as Environmental Sensitive Area (SEA) rank 1. Existing forests and protected areas within the core area conserve a wide range of habitats and landscapes, covering approximately $69.51 \mathrm{~km}^{2}$ (6951.44ha).

In terms of governance, the core area is of the concern of various stakeholders. A variety of legislative, regulatory and management mechanisms are coordinated to ensure the protection and conservation of landscapes, ecosystem, and biodiversity within the terrestrial component of the Reserve. In the core protected area, these mechanisms include federal legislation (Wildlife Act 1972, Environmental Quality Act 1974), provincial legislation Wildlife Act 1972, Fisheries Act 1985, Forestry Act 1984, Environmentally Quality Act 1974 (Act 127) \& Subsidiary Legislation, Land Rules Applicable to the States in Malaysia, and the Town and Country Planning Act 1976) and management plans. Adjustment to the core area may occur through treaty, negotiations and the outcome of community based land and resource use planning processes.

The buffer zone is unique, as it surrounds the whole catchment area/core zone in order to prevent the encroachment of development in the core zone. Terrestrial buffer zones include all protected and unlogged major valleys and lake watersheds in the Reserve, totaling approximately $20.56 \mathrm{~km}^{2}(2,056 \mathrm{ha})$. These areas are subject to forest planning that may lead to refinements in the application of the zonation model, including the establishment of further transition areas. It also ensures that the area remain a productive natural environment for migrating birds and other wildlife while providing for compatible public use (such as transportation and tourism). Buffer and transition zones promote biodiversity and conservation under a wide range of status and management plans.

The third region is the transitional zones. With the coverage of $30.20 \mathrm{~km}^{2}$ (3,020ha) comprising of private and public land ownership, sustainable resource management has been suggested as tools for development. These areas are subjected to ongoing planning that may lead to further refinements in the application of the zonation model, including the establishment of buffer zones. Tasik Chini is gaining a serious attempt in terms of conservation and reviving the status of the 'dying' lake from various stakeholders. An allocation of RM3.5million had been approved by the Tourism Ministry to refurbish the lake under the 9th Malaysia Plan (The Star on line 2008 December 15). Besides funding, a closer collaboration of agencies such as the Land and Mines Office, Forestry, Drainage and Irrigation agencies, Orang Asli Affairs Departments and Felda are needed to check and control activities detrimental to the area (Khoo 2008).

\section{Sustainable Livelihood of The Jakuns: The Local Practices}

Orang Jakun falls under the Proto Malay tribe, and they are believed to originate from Yunnan (South China) 2500BC. They are the second largest group in a Proto Malay group after the Temuans. Most of the Jakun people stay in South Pahang and North Johor. The Jakun speaks a dialect that belongs to the same Australasian family of languages as Malay. Local variations among the Jakun communities, including dialect, are due to contacts with 
other groups, historical factors and geographical location. Their social organization exists as informal and loosely knit units in comparison to their Malay neighbours. Majority of them practice animism and only a few families are Muslims.

Often, livelihood of orang Asli in Malaysia is described and proved to be the "poor and marginalized minority groups' by the anthropologists, economies and planners. Staying far from the main centre of development, the social economic activities of the community are closely link to the natural resources around them. They, however, are encouraged to settle in a permanent settlement for better life. Most of the young go to schools. Meanwhile the youths lack entrepreneurship opportunities. An effort to increase the standard of living of the Orang Asli also one of the major considerations in Ninth Malaysian Plan and of recent. However, according to the statistics from the Jabatan Hal Ehwal Orang Asli (JHEOA), poverty rate in Tasik Chini is among the highest of all the orang asli communities in Malaysia. With two different situations on achievement and setbacks, a question poses here is that: Does the existing livelihood of the Orang Asli meets their traditions and future prospect?

Using qualitative and quantitative data collected from a survey conducted in 2007, and several visits and a consultation campaign carried out in 2008 and May 2009, this section illustrates the existing livelihood and socio-economy as well as their knowledge on Biosphere Reserve. The results of the survey in six kampongs shown in Table 1, further revealed that their future empowerment and sustainability. Six kampongs have given their full cooperation during the survey, resulting from respondents of 80 households. More than 50 percent of the total respondents were from Kg Gumum, followed by Ulu Gumum, Kg Cendahan, Kg Tanjung Puput, Kg Melai and Ulu Melai.

\subsection{Socio-Demography of the Community}

Generally, the Jakun is a communal society. They live closely with their family members in several areas surrounding the lake of Chini since 1960s. The Jakuns prefer staying in an individual dweller as most of them are nuclear family units. However, their siblings or the children's live nearby their home or dwellers. Pak Bahrin, who stayed in Kg Puput, for example, told us during our recent visit that, all members staying around him was his siblings, sons and relatives. Meanwhile another key respondent told us that one or at least two families stayed in one house, depending on the size of the house and family members.

In terms of socio demography, there exists two major groups of Jakuns in Tasik Chini, consisting of the older and the younger generation. The older generation, regards themselves as the 'settlers' of the areas. On the other hand, the younger generations became the 'followers' as many of them were the family members of the first generation. The younger generation's family size was almost similar to the older generation, ranging over 8 to 12 members in a unit. The average age of the respondents was 40, and this figure proved that the population was relatively young. The group the $30-40(30 \%)$ years followed the most represented age group between 40 and 50 years $(15 \%)$. As for their family members, the average age was even younger. The most dominant age group was $5-12$ years. In terms of gender, their family members consist more female than males.

Majorities of the respondents were married while only a few were singles and widows. According to the respondents, they started their family life cycle at the age of at least 17 years old. However, among their family members, around $40 \%$ were married while others were still single. The overall data showed that the life cycle of a family in the Orang Asli community began at an early stage of youth age group.

\subsection{Family Livelihood and Their Routines}

This study also explores the family routines, especially what responsibilities every member has to play. From the survey, the families' routine was simple. For a family unit, the wife or a female usually handled domestic works. They played important roles in managing daily or routine house works such as cooking, washing and looking after their children. Meanwhile, the husband acted as the head of the household, often, has the responsibility of seeking money, supporting the family needs and working outside the domestic sphere of their homes.

Looking into the decision making and division of labour of each household, the results of the survey revealed that, the Jakuns are males dominated society. In other words, the decision making in domestic roles in a family domain was done by females, meanwhile the external sphere, particularly the family's economy was dominated by males. Decision makings among the respondents are shown in Table 3. As what has been generally accepted that the women roles are dominant in the household responsibilities in rural societies or economy, the result of the study also showed a similar trend. The wife usually functions most roles, even though the breadwinner of the family is still the husband.

However, in farming and agricultural activities, dual family roles were quite dominant. The wives, besides managing domestic work and well being of the family members, played active roles in the modern economy, 
including rubber tapping, harvesting local fruits, collecting herbals and oil palms (Habibah et al 2009, Fernandes 2009). On the other hand, their children or the younger generations were seen to experience specialized roles. The youngs were encouraged to go to school, as many of their parents accepted the fact that access to education would lead to better livelihood. There is a primary school located in Kg Gumum and a secondary school in Felda 1 , within the vicinity of their kampongs. According to Pak Bahrin, one of the main key respondents, only during the school holidays, the youngs were brought to the forests to help gathering forest herbs and food. Overall each of the Jakun family members has the roles to play for their survival, both, economically and socially (Habibah et al 2009).

\subsection{Social Integration in The Community}

Social integration between units of family, neighbours and members of the community at large were also sought in the survey. Based on several questions as shown in Table 3, 70\% of the respondents told that their respects and cooperation between members of community were 'good like before'. Only $6.3 \%$ of the respondents mentioned that this aspect was worsening recently. Meanwhile the social bonding between neighbours were very good as before. In terms of relationship within the community, the same trend also existed. More than $70 \%$ mentioned that their social relations within the local community were good like before and about $21 \%$ of them have mentioned that this situation was even improved.

In fact, local knowledge among the younger generation was slowly disappearing. Taking for examples the tradition of building new house, Tok Batin described the younger generation was no longer showing their interests. In fact, among the parents, their native skills in search of trees, leaves and woods' suitabilities for building new houses were no longer taught to their children. This was even worse with the medicinal herbs as the young has little opportunities to explore the surrounding forests.

In terms of their participation in the NGOs or political bodies, the respondents' views are shown in Table 3. Their involvements with NGO's is closely related to Sustainable Development Network (SUSDEN). In fact, this has led to the formation of the Tasik Chini Working Committee, which comprises the village development and security committee head, the heads of the five villages, SUSDEN representative Baharin Sunta and Tok Batin Awang Alok and Chini state assemblyman as the adviser. The committees adopted the theme 'Sustainable Village Initiative' to look after the well-being of the lake and increase the settlers' sources of income and quality of life (Begum, 2006).

\subsection{Socio-Economy Of Community In Tasik Chini}

This part describes the socio-economy of the Jakun community. The Jakun performed both, the traditional and modern economic activities. In the older days, the Jakuns realized on shifting cultivation, hence, seldom stayed in permanent places. Instead, they moved to another place, and returned to cultivate on the same plot many years later. Today, most of the Jakuns stayed permanently in one settlement. According to the Tok Batin, almost the majority of his village folks have settled in permanent land, possessing the rights of developing their land, either through land tenure or property ownership. Kg Gumum is the main settlement of the community, with many of the urban facilities, electricity and water were provided by the governnent.

Due to the above changes, majority of the families also showed changes in managing their resources and capitals. The families managed their own rubber and oil palm plantation as these were the major cash crops in the area. In fact, they were highly involved in the modern small-scale agriculture. Due to the high demand of the forest products recently, some of the Jakuns ventured seriously in collecting rattan, bamboo, wood, resin, roots and medicinal plants. The products were either sold to the middleman which assisted them at their kampongs, or they managed individually, by selling directly in the nearby town, Pekan. The survey also proved that the Jakuns' involvements in the modern economic activities in the nearby logging companies, plantation and factories (Table 4).

The local community also practiced hunting for subsistence living during the older days. Wildlife species commonly caught are the wild boars, deer species (Pelandok, kancil and kijang) and monitor lizards. However in recent days, according to the local leader, even though wild boar or babi hutan is common in the adjacent oil palm plantation schemes, many of them were reluctant to continue hunting as a means of daily food supply. One of the reasons was that they perceived themselves as being less civilized if they were still consuming exotic species, in comparison to the easy way of buying and consuming chicken, beef and other farmed meat from the night markets and mobile traders entering their villages. 


\subsection{Sustaining Incomes in Tradisional and Modern Economy}

This paper also demonstrates the economic activities among the household and community at large. In general, the communities were involved with several occupations. They are culturally taught to survive not only with one job. Instead, they worked within the areas of natural resources and the community's ownership. Taking fishing for example, they only fish in the certain spot of the lake. According to Tok Batin, everybody knew whose areas and who have the rights to fish and collect forest herbs.

Even though the Orang Asli is a male dominant society, our recent study showed a female's dominant economy is gradually increasing. One of the outstanding achievements is the effort of Kak Nor, a women entrepreneur in venturing handicrafts in Kg Gumum. Together with the local women of surrounding kampongs, they embarked on a cottage industry. She was capable of attracting a business venture into her Kampung. With a smart collaboration between the locals and the Biotropics Malaysia Berhad (Biotropics), they set up the herbal processing facility in $\mathrm{Kg}$ Gumum. The venture has enabled the women to make the leap from merely collecting wild herbs in the jungle as part of domestic work to engaging in the value-added activities of modern economy. These include drying, grinding, packaging and transporting the herbs. According to Fernandez (2009), income generated from spending a whole day in the forest searching for the root, has enabled them to obtain better incomes of an average price of RM2 to RM3 a kilogram. Added to this, Kak Nor mentioned that their involvement had assured them of getting about RM500 a month, and most of them were satisfied with their moves.

During the survey, several aspects of well being and economic enhancements were also captured. Table 5 reveals the aspect concerning the cost of living, traditional activities and wealth. The respondents seemed to agree that the cost of living has not changed much, as about $35 \%$ of the respondents have mentioned them as 'good as before' and 'better now'. In terms of changes of wealth, rent and land tenure, almost half of the total respondents agreed that the situation was stable. In fact, more than $50 \%$ of the respondents have agreed that they were in the better position for continuing their traditional activities in the future, especially for the sake of sustainable livelihood in the context of Biosphere Reserve.

The authors also solicited the possibilities of venturing in ecotourism. Only $20 \%$ of the respondents have mentioned that this sector would be better in the future. An interview with Pak Bahrin, previously was an active host of Orang Asli ecotourism in his kampong, seemed to support the fact. He mentioned that the youth, being the majorities, were not thinking ahead of ways or possibilities in expanding ecotourism. Perhaps, issues of lacking entrepreneurship among them were only of recent phenomenon in his community but common to the rurals, especially among the marginalized group. Due to age factor, his work in tourism and guiding tourists were only seasonal. Fewer tourist arrivals had led him to stress the fact that existing ecotourism was not encouraging him, besides, "mood tak ada..." Overall the reasons underlying the capability of the local tourism entrepreneurs was due to lack of literacy, tourism skills and knowledge, product development and marketing, tourism awareness and capital.

However, our key respondent who is operating the only resort in the area, believed that ecotourism is a promising activity that has helped to increase both, the family and community's well being. To gain such benefits, the locals need to excel a good host-guest relationship while delivering or providing services. The Jakun's relationship with their guests was very close and intact during the olden days. Their friendliness, smiling faces and soft spoken voices can be experienced whenever they interacted with the tourists in a formal or informal situation. These attitudes perhaps, should be continuously inculcated in the communities, especially when a community-based ecotourism is one of the future plans for Tasik Chini Rizab Biosfera.

\subsection{Access to Basic Amenities and Infrastructures}

Several aspects of well being of the community were detected from the pattern of possession and access to facilities. Basically, staying in kampongs surrounding the Tasik Chini which is about 50 kilometers from Pekan, does not mean that the facilities of urban needs are easily accessible to the local community.

In the survey, we recorded the pattern of the possession of basic amenities in their house as well as access to public facilities. From the 80 responses shown in Table 6, the overall consumption of the selected items in their ever day life was still inadequate. $\mathrm{Kg}$ Ulu Gumum and $\mathrm{Kg}$ Ulu Melai have no water supply. In fact, there was no electricity. Overall, $\mathrm{Kg}$ Gumum is well equipped with basic amenities and public infrastructures in comparison to all kampongs of the Jakun in Tasik Chini. According to Pak Bahrin, they have to use electricity only at night. As of today, the facilities were far better. In fact, the families of Kg Gumum had the opportunities of consuming common electrical and household goods, as there was a sufficient supply of water and electricity. As the kampung was also accessible through both, road and the waterways, members of the community took the 
opportunities to possessing transportation, among others are the car, motorcycles and trucks as well boats for better jobs, travel and livelihood.

\subsection{Ensuring Sustainability of Community and Migration Pattern}

Sustainable living in Tasik Chini will certainly ensure that the community will not move or migrate from the origins. Do the Jakuns migrate from this locality? Where do they go? Why are they moving from their origin? Based on the survey conducted by the team members, Table 7, revealed that the Jakuns were not in favoured to migrate farther away. In other words, they tried to avoid total migration from one places to another, as they used to practice during their early livelihood. However, there exists two types of migration. Firstly, is a short distance migration, which occurred within the locality of the society of Jakun and also in Tasik Chini. The members of Kg Gumum moved to the new resettlements of Kg Ulu Gumum, just a distance from their original places. Secondly is long distance migration, which only a small number of the community members were involved. This includes migration within the district of Pekan and within the state of Pahang and east coast region of Peninsular Malaysia. Of all this two pattern, choosing the new plot of lands for resettlement, work and marriage were mainly the push factors. The pull factors, on the other hand, was better access to basic amenities, education and family matters. Definitely, the above results support that the locals avoid migration as a means of ensuring the sustainability of Tasik Chini.

\section{Perceptions of Local Community on Biosphere Reserve}

The study also explores the local community's perceptions on the Biosphere Reserve. A group of Final year students were given an opportunity to handle a consultation programme, as part of the part of their tasks in the participatory involvement course. They selected two kampongs, namely $\mathrm{Kg}$ Gumum and $\mathrm{Kg}$ Puput as these kampongs is the major settlement of the Jakun. It was during the consultation programme, the students took the initiatives to communicate, explain and promote the concept of Biosphere Reserve. At the same time, they managed to survey 26 families, which explored their views, aspiration and knowledge on Biosphere Reserve and Tasik Chini as the home for the Jakun.

One of the fundamental barriers of engaging Jakuns in the Biosphere Reserve was the difficulty to quantify benefits. Some of the household heads were quite critical on matters concerning the Biosphere Reserve, especially on the idea, concept and mechanism that would benefit all of them as the local community. In fact, Tok Batin who is the local leader, kept mentioning and emphasizing that, interests and benefits could only be understood, appreciated and enhanced, when his people could have seen, relate and consumed real activities in their everyday life.

An overall attempt to consult the communities was quite extensive. The first campaign was held in May 2008 while the second campaign took place in August 2008. The proceeding effort act as a platform to inform and promote public that Tasik Chini needs to be restored and preserve as the national heritage. Meanwhile the second campaign was in the form of a closer in person consultation. From the short visit in Kg Gumum and $\mathrm{Kg}$ Puput, the teams managed to interview 26 households, and listen and talk with the family members about the Biosphere Reserve. Even though information of the topic was shallow, but concerns about the Biosphere reserve future development and conservation programmes have attracted the head of the household of the Jakuns. This was because the Biosphere Reserve concern with the sustainability of the lake, the forest as well as the community.

In terms of conservation, they seemed to agree that, as long as the programme of the Biosphere Reserve did not disturb their daily lives, they would support the activities. They knew about the depletion of lotus, and the reasons why the tourists are slowing down in numbers. In 2007, the lake managed to attract only 17,000 tourists (Mohd Shukri Ishak 2008). However, from our experiences, not all members of the community were involved in tourism industry, and have the direct contact with the tourists.

\section{Conclusion}

This study has provided the evidence that the local practices among the aboriginals of Tasik Chini are manageable and aligned with the needs of sustainable development. These can be summaries as follows: i) The Jakuns are the guardian of the locality whereby their concerns of the sustainability were instil in the social, economic and appreciation of environment. The subsistence ways of living in terms of fishing and forest hunting supported the fact that the lake and the forest provide the sustainability of Tasik Chini. The local integrity of the community was also exhibited, consumed and continued in various activities, especially at the neighbourhood and familiy levels.

At the same time, the Jakun livelihood is connected closely to the modern economy. Involvements in plantation economy and other formal works in the nearby area have helped the Jakuns to transfer their nature of living in 
stable settlements, not to the expense of limiting their practices in the traditional ways of appreciating forests called 'rayau'. In a simple manner, through 'rayau', learning to live in nature and forest as well as to utilizing forest resources for economic enhancements can be harnessed in the community and among younger generation.

This study also found that the Jakuns believed that ecotourism was one of the promising economic activities they could venture. Among the issues of their concern is the pattern of tourists' arrivals, which saw a gradually droppings due to the lake's attractions have been losing its appeals. What is interesting is that the blending the conventional offerings with knowledge-led offerings was very much received. They showed their acceptance of new ideas of developing the community based ecotourism as it would be benefiting them or could offer them chances to be involved with the economy. They were also concerned with the nature-based ecotourism as the sources of continuity of the local tradition. Meanwhile, the offerings of the community based ecotourism, would need them to provide accommodation, cultural arrangements, food and alike, which perhaps generated various employment, both for older and younger generation.

In terms of community's integrity or social sustainability, the study revealed that the community and the social units of the Jakuns have yet kept the belief of getting and living as the one communal. Migration is only small part of the life cycles, due to many circumstances. Among others are migration for better living due to working commitment in modern economy and services is only dominant among the Young, especially the second and third generation of the community. Finally, the empowerment of the women in the modern economy is increasing even though the numbers was still small. The Kak Nor's an effort to display kercut crafts should lead many women to participate in handicrafts. Incentives should be given and training the trainers programme be accessible to the potentials.

Based on the above findings, one of the possible ways of ensuring the locals involvements in conservation and sustainable development is the empowerment of the locals in the community-based ecotourism. This concept and approach, even though is relatively new, through proper engagement at local level, each kampong has the chances to showcase her uniqueness and culture. Each of the villages should provide Trails of Tasik Chini with different specialization especially in the exploration of local knowledge activities including outdoors and adventures. The 12 lauts of Tasik Chini can serve the myths exploration of Khmer Kingdom. The villages can also work closely with the tour operators to manage serving the tourists. In fact, cultural programmes during the school holidays should be encouraged as these would ensure the involvements of the younger generations, especially school children and youth.

As a conclusion, issues of the future livelihood and the socio-economy of the Jakuns in Tasik Chini need to be sought and manage in a holistic manner. Further research and strategic plans on the community need to be tackled. The aspiration, culture and socio-demography of the native livelihood as well as the generational gaps between the old and young should be heard and resolved. The community, on the other side, should look at the establishment of Tasik Chini as the pioneer Biosphere in Malaysia as the precious opportunity and platform to enhance better living, at the onset of not compromising the efforts to conserve the natural and cultural heritage of Jakun and Malaysia. Perhaps, the local practices are invaluable assets for sustainable livelihood.

\section{References}

Begum, F. (2005). Wednesday July 27. Community initiative at Tasik Cini. [online] Available.http://www.allmalaysia.info/news/story.asp?file=/2005/7/27/state/11313436\&sec=mi_pahang (August 2, 2009).

Brocklesby, M.A and Fisher, E. (2003). Community Development in Sustainable Livelihoods Approaches: An Introduction. Community Development Journal. 38 (3), 185-198.

Campbell, L. M. (1999). Ecotourism in rural Developing communities. Annals of Tourism Research, 26 (3), 534-553.

Fernandez, C. (2009). The Star, Thursday May 21, 2009 No longer just herb collectors. [online] Available. http://thestar.com.my/metro/story.asp?file $=/ 2009 / 5 / 21 /$ central/3938755\&sec=central (May 21, 2009)

Habibah, A, Hamzah, J, Mushrifah, I, Ari Kurnia, Yussof, I, Omar, M. (2009). Empowering Economic of Aboriginals of Tasik Chini in Regional Development of East Coast Region. Proceeding National Conference of Malaysian Economic IV, 2009. Faculty of Economy and Business, Universiti Kebangsaan Malaysia, Bangi. Vol $1,175-188$.

Khoo, S. (2008). Pahang wants to revive Tasik Chini. The Star December 15, 2008. [online] Available. http://thestar.com.my/news/ story.asp?file=/2008/12/15/nation/2810048 \&sec=nation (February 2, 2009) 
Mohd Shukri, I. (2008). Tasik Chini: the Lotuses Will Bloom Again. Bernama. January 30, 2008. [online] Available. http://www.bernama.com/bernama/v5/newsindex.php?id= 311231 (Februaury 15, 2009).

Moran, M, Wright, A, Reneha, P, Anna Szava, A, Beard, N and Rich, E. (2007). The Transformation of Assets for Sustainable Livelihoods in a Remote Aboriginal Settlement. [online] Available. http: www.desertknowledgecrc.com.au/DKCRC-Rep-28-Transformation-of-Assets.pdf (May 12, 2010).

New Straits Times. 10 Disember 2007. Lost city of Khmer empire?

Tonle Sap Conservation project. (2006). Options and strategy for sustainable livelihoods support In the core areas of The Tonle Sap Biosphere Reserve 2006-2011. [online] Available. http:www.tsbr-ed.org/english/ projects\&program/dwld_report.asp?fn. (May 12, 2009).

UNESCO (2009). United Nations Proclaims 22 New Biosphere Reserves [online] Available. http://blogs.nationalgeographic.com/blogs/news/chiefeditor/2009/05/united-nations-proclaims-22-ne.html (December 10, 2009).

UNESCO (2010). Biosphere Reserve. [online] Available. http://portal.unesco.org/science/en/ev.php-URL_ID=4801\&URL_DO=DO_TOPIC\&URL_SECTION=201.html. ( July 28, 2010)

Table 1. Number of Respondents

\begin{tabular}{|l|c|c|}
\hline Villages & Frequency & Percent \\
\hline Kg Gumun & 45 & 56.3 \\
Ulu Gumun & 15 & 18.8 \\
Kg Cendahan & 5 & 6.3 \\
Kg Tanjung Puput & 5 & 6.3 \\
Kg Melai & 2 & 2.5 \\
Ulu Melai & 8 & 10.0 \\
\hline Total & 80 & 100.0 \\
\hline
\end{tabular}

Table 2. Background of the Respondents

\begin{tabular}{|c|c|c|c|}
\hline $\begin{array}{l}\text { Aspects of respondent' } \\
\text { background }\end{array}$ & Aspect of answers & Frequency & Percent \\
\hline \multirow[t]{2}{*}{ Head of the household } & Yes & 76 & 95.0 \\
\hline & No & 4 & 5.0 \\
\hline \multirow{3}{*}{$\begin{array}{l}\text { Respondent relationship with } \\
\text { the household heads }\end{array}$} & Husband & 35 & 43.8 \\
\hline & Wife & 41 & 51.2 \\
\hline & In-laws and sons/daughter & 4 & 5.0 \\
\hline \multirow[t]{2}{*}{ Gender } & Males & 39 & 48.8 \\
\hline & Female & 41 & 51.3 \\
\hline \multirow[t]{6}{*}{ Religion } & No religion & 10 & 12.5 \\
\hline & Animism & 51 & 63.8 \\
\hline & Islam & 4 & 5.0 \\
\hline & Christian & 7 & 8.8 \\
\hline & Buddhist & 2 & 2.5 \\
\hline & Others & 6 & 7.5 \\
\hline \multirow[t]{7}{*}{ Age group } & $18-20$ years & 5 & 6.3 \\
\hline & $>20-25$ years & 4 & 5.0 \\
\hline & $>25-30$ years & 14 & 17.5 \\
\hline & $>30-40$ years & 24 & 30.0 \\
\hline & $>40-50$ years & 16 & 20.0 \\
\hline & $>50-60$ years & 14 & 17.5 \\
\hline & $>60-75$ years & 3 & 3.8 \\
\hline
\end{tabular}


Table 3. Social Integration of families and communities

\begin{tabular}{|l|l|c|c|}
\hline Aspect & Responses & Frequency & Percent \\
\hline Respect/cooperation among members & Worsen now & 5 & 6.3 \\
& Worse like before & 8 & 10.0 \\
& Good like before & 56 & 70.0 \\
& Better now & 11 & 13.8 \\
Social relationship within local & Worsen now & 1 & 1.2 \\
community and NGOs. & Worse like before & 3 & 3.8 \\
& Good like before & 39 & 48.8 \\
& Better now & 37 & 46.2 \\
The existing situation of Family/ & Worsen now & 3 & 3.8 \\
neighbours bonding & Worse like before & 11 & 13.8 \\
& Good like before & 50 & 62.5 \\
& Better now & 16 & 20.0 \\
\hline
\end{tabular}

$\mathrm{N}=80$ respondents $(100 \%)$.

Table 4. Economic Activities

\begin{tabular}{|c|c|c|c|}
\hline Aspects/ answers & & Frequency & Percent \\
\hline \multirow[t]{2}{*}{ Are you working } & Yes & 47 & 58.8 \\
\hline & No & 33 & 41.3 \\
\hline \multirow{11}{*}{ Sectors } & Not working & 33 & 41.3 \\
\hline & Agriculture & 26 & 32.5 \\
\hline & Forest based & 6 & 7.5 \\
\hline & Fishing & 2 & 2.5 \\
\hline & Crafts & 3 & 3.8 \\
\hline & Manufacturing & 1 & 1.3 \\
\hline & Retailing & 2 & 2.5 \\
\hline & Hotels & 1 & 1.3 \\
\hline & Services & 3 & 3.8 \\
\hline & Transportation & 1 & 1.3 \\
\hline & Others & 2 & 2.5 \\
\hline \multirow[t]{4}{*}{ Working status } & Not working & 33 & 41.3 \\
\hline & Entrepreneur & 1 & 1.3 \\
\hline & Paid workers & 11 & 13.8 \\
\hline & Working individually & 35 & 43.8 \\
\hline \multirow[t]{6}{*}{ Family monthly income } & Not mentioned & 31 & 38.8 \\
\hline & RM100 -RM300 & 17 & 21.3 \\
\hline & More than RM300 -RM500 & 13 & 16.3 \\
\hline & More than RM500 -RM1,000 & 12 & 15.0 \\
\hline & $\begin{array}{l}\text { More than RM1,500 - } \\
\text { RM3,000 }\end{array}$ & 6 & 7.5 \\
\hline & More than RM5,000 and above & 1 & 1.3 \\
\hline
\end{tabular}

$\mathrm{N}-80$ respondents. 
Table 5. Economic of families and communities

\begin{tabular}{|c|c|c|c|}
\hline Aspect & Responses & Frequency & Percent \\
\hline \multirow[t]{4}{*}{ Cost of living } & Worsen now & 17 & 21.3 \\
\hline & Worse like before & 43 & 53.8 \\
\hline & Good like before & 8 & 10.0 \\
\hline & Better now & 12 & 15.0 \\
\hline \multirow{4}{*}{$\begin{array}{l}\text { Chances to continue traditional economic } \\
\text { activities }\end{array}$} & Worsen now & 4 & 5.0 \\
\hline & Worse like before & 25 & 31.3 \\
\hline & Good like before & 42 & 52.5 \\
\hline & Better now & 9 & 11.3 \\
\hline \multirow[t]{4}{*}{ Possibility of upgrading their skills } & Worsen now & 1 & 1.3 \\
\hline & Worse like before & 38 & 47.5 \\
\hline & Good like before & 33 & 41.3 \\
\hline & Better now & 8 & 10.0 \\
\hline \multirow{4}{*}{$\begin{array}{l}\text { Competition in economic/occupational } \\
\text { activities }\end{array}$} & Worsen now & 16 & 20.0 \\
\hline & Worse like before & 27 & 33.8 \\
\hline & Good like before & 33 & 41.3 \\
\hline & Better now & 4 & 5.0 \\
\hline \multirow[t]{4}{*}{ Chances to wealth and rental ownership } & Worsen now & 5 & 6.3 \\
\hline & Worse like before & 31 & 38.8 \\
\hline & Good like before & 38 & 47.5 \\
\hline & Better now & 6 & 7.5 \\
\hline \multirow[t]{4}{*}{ Existence of land tenure } & Worsen now & 2 & 2.5 \\
\hline & Worse like before & 14 & 17.5 \\
\hline & Good like before & 53 & 66.3 \\
\hline & Better now & 11 & 13.8 \\
\hline \multirow{4}{*}{$\begin{array}{l}\text { Involvement on ecotourism } \\
\text { entrepreneurship }\end{array}$} & Worsen now & 2 & 2.5 \\
\hline & Worse like before & 19 & 23.8 \\
\hline & Good like before & 42 & 52.5 \\
\hline & Better now & 17 & 21.3 \\
\hline
\end{tabular}

$\mathrm{N}=80$ respondents $(100 \%)$ 
Table 6. Possession of Basic Household Amenities

\begin{tabular}{|c|c|c|c|c|c|c|c|c|c|c|}
\hline \multirow[t]{2}{*}{ Possession } & \multicolumn{2}{|c|}{ Kg Gumum } & \multicolumn{2}{|c|}{$\begin{array}{l}\text { Kg Ulu } \\
\text { Gumum }\end{array}$} & \multicolumn{2}{|c|}{ Kg Cendahan } & \multicolumn{2}{|c|}{$\begin{array}{l}\text { Kg } \\
\text { Tanjung } \\
\text { Puput }\end{array}$} & \multicolumn{2}{|c|}{$\begin{array}{l}\text { Kg Ulu } \\
\text { Melai }\end{array}$} \\
\hline & No & $\%$ & No & $\%$ & No & $\%$ & No & $\%$ & No & $\%$ \\
\hline Television & 34 & 75.6 & 4 & 26.7 & 0 & 0 & 0 & 0 & 3 & 37.5 \\
\hline Radio & 19 & 42.2 & 5 & 33.3 & 0 & 0 & 2 & 40.0 & 4 & 50.0 \\
\hline Astro & 2 & 4.4 & 0 & 0 & 0 & 0 & 0 & 0 & 0 & 0 \\
\hline Computers & 2 & 4.4 & 0 & 0 & 0 & 0 & 0 & 0 & 0 & 0 \\
\hline Video & 18 & 40.0 & 0 & 0 & 0 & 0 & 0 & 0 & 2 & 25.0 \\
\hline Refrigerator & 11 & 24.4 & 0 & 0 & 0 & 0 & 0 & 0 & 1 & 12.5 \\
\hline Electricity & 36 & 80.0 & 1 & 6.7 & 1 & 20.0 & 0.0 & 0.0 & 2 & 25.0 \\
\hline Pipe water & 41 & 91.1 & 1 & 6.7 & 1 & 20.0 & 0 & 0.0 & 1 & 12.5 \\
\hline Toilet & 22 & 48.9 & 4 & 26.7 & 3 & 60.0 & 0 & 0.0 & 1 & 12.5 \\
\hline Fans & 18 & 40.0 & 0 & 0.0 & 0 & 0.0 & 0.0 & 0.0 & 0 & 0.0 \\
\hline Telephone & 17 & 37.8 & 4 & 26.7 & 3 & 60.0 & 0 & 0.0 & 4 & 50.0 \\
\hline Gas cooker & 34 & 75.6 & 12 & 80.0 & 2 & 40.0 & 2 & 40.0 & 4 & 50.0 \\
\hline Sette & 9 & 20.0 & 1 & 6.7 & 0 & 0.0 & 0 & 0.0 & 0 & 0.0 \\
\hline
\end{tabular}

$$
\mathrm{N}=80 \text { respondents }(100 \%)
$$

Table 7. Migration Pattern

\begin{tabular}{|l|l|}
\hline Migration Aspect & \multicolumn{1}{|c|}{ Description } \\
\hline $\begin{array}{l}\text { Migration occurs among the family } \\
\text { members }\end{array}$ & $\begin{array}{l}\text { Among the kg, Kg Gumum dominates the migrant members. } \\
23 \text { members of family migrated. Families members - are } \\
\text { usually the child of the household. Among others are the } \\
\text { brothers, sisters and children. }\end{array}$ \\
\hline Points of migrants & $\begin{array}{l}\text { Short distance migration, - in the same kampong, district and } \\
\text { state. }\end{array}$ \\
\hline Reason of migration & $\begin{array}{l}\text { Marriage was the top reasons, followed by jobs requirement } \\
\text { and families. }\end{array}$ \\
\hline Socio-economic status & Agriculture, manufacturing and small business \\
\hline Interaction with the origin & $\begin{array}{l}\text { Sources of remittance; even for a small amount of money, } \\
\text { social aspects. }\end{array}$ \\
\hline
\end{tabular}

